\author{
Zakharova Oksana Yuryevna ${ }^{1}$
}

\title{
INTERACTION OF ARTS IN DIPLOMATIC CEREMONIALS OF THE USSR (EARLY 20S - MID 80S XX CENTURY)
}

Keywords: international relations, art of diplomacy, foreign visits, cultural programs, state image

ABSTRACT: The relevance of the study is determined both by the insufficient study of the diplomatic ceremonials of the USSR, and the fact that knowledge of the laws of their functioning expands our ideas about the cultural component of the life of Soviet society.

Taking into account the absence in Russian historiography of a special study devoted to the problem of the interaction of arts at diplomatic ceremonies, the author set the goal to conduct a comprehensive research of the problem of the interaction of arts in diplomatic ceremonials.

The article considers the stay of the Diplomatic Corps in Moscow from the point of view of the influence of foreign policy priorities on the norms of the diplomatic protocol.

Examples of balls, sports, receptions, organized by the embassies of Germany and Italy, which in the 20-30s played a leading role in the life of the Diplomatic Corps, are given.

The content of concert programs of official foreign visits, which contributed to the creation of a positive image of the country on the world stage, is analyzed.

For the first time the term "diplomatic counterculture" is introduced into scientific circulation - an intentional violation of the diplomatic protocol and diplomatic etiquette in order to achieve a specific result in international communication.

It was revealed that the diplomatic ceremonial in itself is a synthesis of arts - the picturesque design of space, music, choreography, costume.

Already in the first years of Soviet power, symbols of power entered the "struggle for power." At diplomatic ceremonies this struggle was in the form of a confrontation between European protocol traditions and the rules of the Soviet diplomatic protocol and etiquette newly created by the employees of the Protocol Division of the USSR People's Commissariat for Foreign Affairs.

1 Doctor of Historical Sciences, Professor, Independent Researcher, mikepriluki@ gmail.com, ORCID: 0000-0002-2143-7020. 
Dress code, concert programs, a list of dishes served - everything had to meet the standards of Bolshevik ideology.

Hospitality is an important component of national politics. The Protocol Division, through its work, tried to destroy stereotypes about the USSR as an evil empire. The multinational Soviet culture contributed to the creation of a positive image of the state on the world stage.

\section{INTRODUCTION}

The relevance of the study is determined both by the insufficient study of the diplomatic ceremonials of the USSR, and the fact that knowledge of the laws of their functioning expands our ideas about the cultural component of the life of Soviet society.

Taking into account the absence in Russian historiography of a special study devoted to the problem of the interaction of arts at diplomatic ceremonies, the author set the goal to conduct a comprehensive research of the problem of the interaction of arts in diplomatic ceremonials.

In Ukraine and abroad we do not know any published study on the interaction of arts at diplomatic ceremonials.

M.A. Alyakrinskaya explores on the example of the history of foxtrot the influence of Soviet ideology on the development of culture (Alyakrinskaya, 2012, p. 25).

A.V. Golubev and V.A. Nevezhin (Golubev \& Nevezhin, 2016, p. 209) in their work studied the methods of Soviet cultural diplomacy, which formed the image of Russia in the world in the 1920s and the first half of the 1940 s.

O.Y.Zakharova considers the political and protocol aspects of visits to the USSR of heads of states, governments, public and political figures (early 20s - mid 80s of the twentieth century) (Zakharova, 2018).

For completeness of coverage of the problem it was necessary to use materials from the fund of the Protocol department (057) of the Archive of the Foreign Policy of the Russian Federation, as well as from the fund 06 (V.M. Molotov's secretariat).

The methodological basis of the study is the principle of historicism and interdisciplinary scientific research using methods of historical, source and art analysis. 
The scientific novelty of the work is a comprehensive study of the problem of the interaction of arts in diplomatic ceremonies, an analysis of the cultural programs of foreign visits and government receptions from the point of view of the social cultural processes taking place in society.

The term "diplomatic counterculture" is introduced into scientific circulation for the first time.

Information on the interaction of arts at diplomatic ceremonies is contained in sources on the history of diplomacy of the Ancient World.

In ancient Greece, in the Roman and Byzantine empires ambassadors were invited to festivals, theatrical performances, given gifts.

For centuries diplomats have been active participants in the cultural life of the states where their service took place. They patronized the famous scientists, writers, artists, musicians of their time, to whom Beethoven devoted several works. The palace of count A.K. Razumovsky was rightfully considered one of the centers of the cultural life of the Austrian capital. In 1815 the son of the last Getman of Ukraine took an active part in the work of Vienna congress, which, being one of the key events in the history of diplomacy, went down in history as a "Dancing congress". The political significance of the Congress is equivalent to its role in the history of the cultural life of Europe.

In Paris of 30-40-ies of the XIX century the embassies of England and Austria were famous for their luxurious feasts. Diplomats had to give receptions and balls, including with the aim of proving the power of their states.

At the court ceremonies of the Russian Empire, members of the Diplomatic Corps were given the most honorable places.

\section{DIPLOMATIC RECEPTIONS IN MOSCOW (20-30S OF THE XX CENTURY)}

By the beginning of the First World War the Russian Empire was a state whose opinion could not be ignored, court ceremonies emphasized the strength and power of the ruling dynasty and were a political program of power. 
The pre-revolutionary protocol was based on a serious legal base, consisting of legal documents developed in the empire, and the provisions adopted at the Vienna Congress in 1815.

In the first years of Soviet authority, representatives of the workers and peasants government tried to ignore the norms of the diplomatic protocol and etiquette, arguing that they were based on bourgeois morality alien to the young Soviet republic. But already at the beginning of the 1920s it became obvious that it was impossible to build partnerships with foreign countries without observing generally accepted European norms, traditions and conventions in international communication.

At a time when the People's Commissariat of Foreign Affairs was headed by G.V. Chicherin, Protocol Division under the supervision of D.T. Florinsky was a collective of creative personalities, who, not afraid to experiment, developed standards of protocol practice that have been relevant for decades.

So, compiled in 1923 by D.T. Florinsky's "Brief instruction on the observance of the rules of etiquette accepted in bourgeois society" was taken as a basis when creating in 1935 a new manual on the protocol "Diplomatic technique" (reprinted in 1938).

From the first years of its existence, the Protocol Division of the PCFA (until November 12, 1923 - the protocol unit (protocol part), took an active part in the preparation of foreign visits to the RSFSR, and since 1923 - to the USSR.

In addition to the development of regulatory documents for the preparation and conducting of foreign visits, employees of the Protocol Division took an active part in organizing diplomatic ceremonies with the participation of diplomats accredited in Moscow and their families.

The peculiarity of staying of the Diplomatic Corps in Moscow was that the embassy employees were in an unusual social and cultural environment, the value system in which was formed by the norms of Bolshevik ideology.

Using the methods of agitation and propaganda, the authorities sought to formulate a negative attitude among citizens towards modern European culture, representatives of which were also employees of diplomatic departments. 
At the beginning of the 1920s the Corps lives rather closed, but in the future, thanks to the activities of D.T. Florinsky and employees of the Protocol Division, the isolation of the Corps from the cultural life of Moscow is no longer so obvious.

It should be noted that the embassies of fascist Italy and Nazi Germany were the peculiar centers of diplomatic life in the capital of the USSR.

In the 1920s the Italian embassy played a leading role in the life of the Diplomatic Corps, forming programs of diplomatic receptions in which, for example, dances were replaced by playing bridge.

Sport, in particular tennis, united the members of the Diplomatic Corps, but did not contribute to their rapprochement with Soviet colleagues, who for the most part came from the workers and peasants, they were not ready to communicate with foreign diplomats either practically or psychologically.

The language of art spoke about this problem at one of the most striking events of Soviet diplomatic life in the early 1930s - a ball in the German mission (1931), at which the Soviet protocol was criticized for being late, not knowing foreign languages, etc. (Sokolin, 1931, p. 74).

At the end of the 1930s the employees of the German Embassy were leaders in social life, but at the same time, German diplomats did not seek to isolate the Embassy and the entire Diplomatic Corps from the PCFA employees, but looked for ways to get closer to them. In particular, discussing protocol issues, for example, - the appearance of a diplomat at official receptions (Barkov, 1939, p. 75).

Ceremonial behavior has the maximum sign and requires special methods to identify and beat the status of partners. Social status largely determines the non-verbal language of communication used during ceremonies.

During the Soviet period all the details of state ceremonies were carefully developed, each of which is an illustration of ethical standards accepted in society.

As in the pre-revolutionary period great importance was attached to the gesture, musical accompaniment, and the language of the costume. Ways to design appearance - important signals, signs of personality. Clothing is a business card. 
The attitude to the diplomat is connected with the perception of the country he represents. In choosing a suit the personal preferences of a diplomatic officer give way to political expediency.

The "expulsion" of the tailcoat in 1939, and even earlier of the cylinder from Soviet protocol practice, was regarded as a victory in the struggle against bourgeois values.

The bearers of ethical norms, alien to the Soviet citizen, were considered modern European dances, which at the same time were included in the programs of most diplomatic receptions.

Diplomatic privileges and immunities extended not only to diplomats, but also to their forms of leisure, in particular, programs of dance parties.

So, the foxtrot banned in the USSR is performed in embassies not only by foreign diplomats, but also by the head of the Protocol Division of the PCFA D.T. Florinsky.

It was allowed to depart from the traditional European diplomatic rules at the so-called "intimate" receptions, one of the organizers of which was D.T. Florinsky.

An "intimate" reception is a reception in an informal situation, where peculiar protocol liberties or surprises were allowed, guests could arrive with a basket of flowers; artists were present not only as participants in concert programs, but also as official guests; the host did not invite the entire Diplomatic Corps to the embassy or restaurant, but its individual representatives, based on his interests (Florinsky, 1927, p. 16, 23).

After 1934 "protocol ambiguity" (contained in the very name of the receptions) could lead to arrest. Apparently, therefore, such receptions did not become a tradition of the Soviet protocol, unlike the Kremlin receptions, the purpose of which, using delicious dishes, was to stun the guests and convince them of the stable development of the Soviet state.

\section{DIPLOMATIC GIFTS AND TREATS}

Works of culinary art are among the symbols of intercultural communication and occupy an important place in the organization of protocol events. 
On September 8, 1941, the siege of Leningrad began, and on December 4, 1941 at a dinner in the Kremlin in honor of the Polish allies they served sterlet in champagne, boiled nelm, turkey, hazel grouses, chickens, asparagus, etc.

The organization in the Kremlin during wartime of generous feasts was, according to Stalin, evidence of the power of the state.

A single approach to solving this problem did not exist.

With the expansion of international contacts, the problem of exchanging memorable gifts both in foreign missions of the USSR and in Moscow itself became more and more topical. Particularly acute was the question of the relationship between the authorities and the guardians of the cultural heritage of the USSR - museum workers.

It should be noted that while interior items not returned to museum vaults remained in the USSR, paintings, sculptures, and decorative and applied art became the cultural property of other states.

The canvases of B.M. Kustodiev (Sokolin, 1928, p. 128), I.I. Levitan, V.V. Vereshchagin (Karahan, 1929, p. 6), S.Y. Zhukovsky, V.I. Zarubina (Barkov,1941, p. 23) were used as diplomatic gifts.

Foreign guests were generously endowed with fur products, some of which can rightly be attributed to works of art. So in 1943, Molotov's wife presented to the wife and daughter of the representative of US President Davis fox and ermine outfits (Golubev \& Nevezhin, 2016, p. 209), and in 1946 a sable fur coat was presented to the Princess of Iran A. Pahlavi personally from I.V. Stalin.

The assortment of Kremlin gifts is very diverse. If in 1944 W. Churchill received caviar, vodka and cigarettes as an official gift, then in 1945 his wife received a 5.58 carat diamond. The "grocery" set of the Prime Minister is more likely a sign of special friendly relations, since in 1944 Churchill was still "one of the lads", and he can be gifted with vodka as well. In turn, C. Churchill earned a diamond for organizing Soviet assistance during the war years. In this connection the question involuntarily arises - for what merits the wives and daughters of the Soviet leaders received very valuable gifts from foreign guests (platinum watches with diamonds to Stalin's daughter from I.B. Tito, etc.) (Molochkov, 1946, p. 32). 


\section{CONCERT PROGRAMS}

The visit of C. Churchill is one of the first independent visits of the wife of the state leader to the USSR. The "female visit" forced the employees of the Protocol Division to depart from the "male code" of the Soviet protocol, in which the presence of women at official receptions was not welcomed. In March 1945, during a visit to Moscow of Czechoslovak President Benesh with his wife, members of the delegation together with their wives were invited to dinner with Stalin (March 28). Ulanova, Maksakova, Kozlovsky, Mikhailov and others performed at a concert in the Central House of the Red Army (CHRA).

The president's wife visited the Moscow Art Theater (play "Russian People") and the ballet school at the Bolshoi Theater.

Visits to the State Academic Bolshoi Theater was included in most programs of foreign visits to the USSR.

In 1922, the famous French politician Herriot watched the ballet "Swan Lake" and "Kopelia" at the Bolshoi Theater.

It is generally accepted that in most cases, guests were invited to the Bolshoi Theater for the ballet "Swan Lake". Our study casts doubt on this statement.

Foreign guests watched the ballets at the Bolshoi Theater: "Giselle", "The Nutcracker", "Kopelia", "Stone Flower", "Red Poppy".

Opera art is represented by vocalists performing on the stage of the Bolshoi Theater or the Central House of the Red Army during government concerts on the occasion of the stay of the head of state or government in the USSR: W. Churchill, de Gaulle, I.B. Tito.

Among the performers you can often find the names of great singers of the twentieth century: Mikhailov, Kozlovsky, Maksakova, Barsova and others.

In their memoirs (Churchill, 1955, p. 228), the guests invited to these concerts. note the performance of the Red Banner Song and Dance Ensemble of the USSR (artistic director A.V. Alexandrov), in the program of which the folk art of the multinational Soviet state was represented by Russian and Ukrainian folk songs, and at concerts in Bolshoi Theater in honor of the visit of de Gaulle (1944) and I.B. Tito (1945) sounded the 
"Poem about Ukraine" (A.V. Alexandrov) (Concert program at the Central House of the Red Army, 1945, p. 84).

The song genre is represented by the works of Bogoslovsky "Dark Night", Novikov's “Smuglyanka", Solovyov-Sedoy's "On a Sunny Meadow", Blanter's "In the Frontline Forest".

At a concert in honor of I.B. Tito in 1945 English and American soldier songs were also performed, followed by the dance of the Don Cossacks.

In the postwar years receptions for diplomatic representatives were arranged, as a rule, on behalf of V.M. Molotov, who, in particular, organized a reception at the Bolshoi Theater on December 21, 1949 on the occasion of the $70^{\text {th }}$ anniversary of Stalin.

The concert program, composed of works by Russian and Western European composers, testifies that Stalin gave particular preference (based on the number of works) to the works of Tchaikovsky, Glinka, Dunaevsky. Folk music is represented by the composition "Suliko" in the processing of Listov. It should be noted that in the concert program we do not see the works of composers of the union republics.

A special tribute to the multinational folk art of the fraternal union republics was expressed by the language of art at a reception in the Kremlin for guests and participants of the VI World Festival of Youth and Students (1957). In between the general dances, hopak, Uzbek dance, Georgian lezginka, Russian dance, Estonian waltz, Belarusian bulba were performed (dances are given in the order in which they are listed in the source). (Reception in the Kremlin, 1957, p. 64).

In the "revitalization" of work with the Diplomatic Corps the main role was given to cultural programs. In the Bolshoi Theater, in the Kremlin Palace of Congresses separate seats were assigned to diplomats. Since January 1963 screenings of feature films have been organized weekly in the representative mansion of the Ministry of Foreign Affairs of the USSR, and authorial evenings of famous cultural figures have been organized monthly. The requirements to take measures to "intensify" work with the Diplomatic Corps were repeated in the decisions of the College in the 70-80s.

In the postwar years the isolation of part of the Diplomatic Corps on an ideological basis continued. 
Such a situation could not but affect the behavior of the members of the Diplomatic Corps in Moscow, in which, along with the traditional, there was a kind of diplomatic counterculture, that is, the intentional ignoring by participants of international communication of accepted protocol norms, as well as the rules of respect and courtesy in international communication.

Behind the seemingly "dry" language of the protocol are specific individuals with their habits and characters.

In some cases protocol violations not only do not interfere with solving the tasks, but even contribute to their implementation, which is confirmed, for example, by the visit of the Prime Minister of Canada Trudeau to the USSR, who in Moscow rode a motorcycle of one of the escort participants in the Kremlin, and in Kiev visited with his wife a disco on Khreshchatyk (Sukhodrev, 1999, p. 220).

In most programs of foreign visits to the USSR visiting Ukraine was an important event, which is especially noticeable in the postwar years. The intellectual potential of Ukraine allowed the republic, despite the Holodomor, repressions, losses during the Second World War, to be one of the most developed republics not only economically, but also culturally.

At the diplomatic ceremonials the high status of Ukraine was emphasized by the presence of Ukrainian folk music and "Poems about Ukraine" by A.V. Alexandrov in concert programs.

\section{CONCLUSIONS}

Thus, as a result of the study it was revealed that the diplomatic ceremonial in itself is a synthesis of arts - the picturesque design of space, music, choreography, costume.

Political symbolism developed in a strict system of borrowings, which are sometimes articulated by the authorities, and sometimes require special explanations.

Already in the first years of Soviet power, "symbols of power" entered the "struggle for power." At diplomatic ceremonials this struggle was in the form of a confrontation between European protocol traditions and 
the rules of Soviet diplomatic etiquette newly created by the employees of the Protocol Division.

Dress code at diplomatic receptions, concert programs, a list of dishes served - everything had to meet the standards of Bolshevik ideology.

Hospitality is an important component of national politics. The Protocol Division through its work tried to destroy stereotypes about the USSR as an evil empire.

The multinational Soviet culture contributed to the creation of a positive image of the state on the world stage.

\section{BIBLIOGRAPHY:}

Alyakrinskaya, M.A. (2012). Dance and ideology: foxtrot in Soviet culture of the $1920-$ 1930s. Bulletin of the St. Petersburg University of Culture, no. 3.

Barkov, V.N. (1939). Diary. Moscow. AFP RF. F. 057. I. 19. F. 113. C. 1. P. 75.

Barkov, V.N. (1941). Letter to A.Y.Vyshinsky. Moscow. AFP RF. F. 057. I. 21. F. 115. C. 4. P. 23. Concert program at the Central House of the Red Army (1945). Moscow. AFP RF. F. 057.

I. 25. F. 123. C. 6. P. 84.

Churchill, W. (1955). World War II. M.,. V. VI. P. 228.

Florinsky, D.T. (1927). Diary. Moscow. AFP RF. F. 057. I. 7. F. 104. C. 4. P. 16, 23.

Florinsky, D.T. Diary. Beginning of the 30s. Moscow. AFP RF. F. 057. I. 10. F. 108. C. 1. P. 14. Fomin, (1944). Letter to A.Y. Vyshinsky. Moscow. AFP RF. F. 057. I. 24. F. 120. C. 7. P. 33. Golubev, A.V. \& Nevezhin V.A. (2016). Formation of the image of Soviet Russia in the surrounding world by means of diplomacy. 1920s - first half of the 1940s. M., P. 209. Herriot's visit to Moscow (1922). Moscow. AFP RF. F. 057. I. 1. F. 101. C. 2. P. 14.

Karahan, (1929). Letter to the People's Commissar of Education of the RSFSR Bubkov. Moscow. AFP RF. F. 057. I. 9. F. 108. C. 7. P. 6.

Molochkov, F.F. (1946). Letter to V.M. Molotov. Moscow. AFP RF. F. 057. I. 6. F. 127. C. 8. P. 32. Sokolin. Diary. 1928. Moscow. AFP RF. F. 057. I. 8. F. 105. C. 1. P. 128.

Sokolin. Diary. 1931. Moscow. AFP RF. F. 057. I. 11. F. 109. C. 2. P. 74.

Sukhodrev V.M. (1999) My tongue is my friend. From Khrushchev to Gorbachev. Memoirs. Moscow. P. 220.

The list of gifts to the Princess of Iran A. Pahlavi (1946). Moscow. AFP RF. F. 057. I. 26.

F. 127. C. 7. P. 18.

Reception in the Kremlin (1957). Moscow. AFP RF. F. 057. I. 41. F. 125. C. 15. P. 64.

Zakharova, O.Y. (2018). How the USSR received distinguished guests. M. P. 495. 